\title{
Teaching Writing to Adult Literacy Students from Harlem and the Bronx
}

\author{
David Pugh, New York State TASC Program
}

\begin{abstract}
This article describes strategies used by the author in intermediate level reading, writing and social studies-history GED classes in Harlem and the Bronx. Since four out of five of the New York State TASC exams are based on reading, I assign extensive reading and discussion, as well as strategies for answering multiple-choice questions. In addition to a textbook, I make copies of readings that emphasize the students' history-beginning with Columbus to African slavery-- and current issues in their communities.
\end{abstract}

Keywords: adult education; GED; TASC; segregation; discrimination

For the past 5 years, I have been teaching writing in a high school equivalency program that is funded by the State of New York and is based in Harlem. This program prepares adult students for the Test Assessing Secondary Completion (TASC), which, in addition to a 50-minute essay, has reading, mathematics, social studies, and science components. My purpose in this article is to illustrate the importance of writing prompts that are truly relevant to learners because they have the potential to engage them and increase their interest in writing. In this way, their skill development can be supported through motivated practice.

\section{Class Overview}

I have intermediate level students in my writing class. After reading their first essays, I learn that they have a broad range of skills in terms of grammar, spelling, organization, and ability to express their thoughts and feelings on paper. Particularly in the case of students who have been out of school for many years, their essays are often one or two paragraphs long, their English grammar is weak, and many have a writing "block" that I have to understand in order to help them become confident writers. At the other end of the skill continuum, students write fluidly with few errors, and they are able to craft thoughtful essays that are between one and two pages long.

Facing these pedagogical challenges, in the course of a semester my goals are three-fold: to teach essential writing skills that have not been covered in the sub-standard high schools that my students have dropped out of; to prepare them to pass the challenging writing section of the TASC; and to empower them to freely express important thoughts and feelings about their life experiences, including why they dropped out 
of high school. As the semester advances and I receive more essays, I am better able to assess and help each student learn new writing skills and self-expression strategies.

Most of the students in this program come from Harlem and the Bronx. They are working class African-Americans, Latinx and recent immigrants. Students range in age from 18 to 60 , but the majority are in their 20s. They share the experience of leaving high school before graduation for a variety of reasons. Since then, most have entered the workforce and some have families. My students' reasons for signing up for this program include going to the 2-year community colleges of the City University of New York, finding jobs that pay more than minimum wage and helping their children with their schoolwork. Keeping their goals in mind allows me to help my students develop stronger writing skills.

On a scale of Level 1 to 4 , I have been teaching intermediate Level 2 students. The writing work that I have developed for the Monday-Thursday day program is described below, including samples of insightful and moving student work from a recent semester.

The pedagogical method that I follow is to provide essay topics that encourage my students to draw on their rich life experiences, while they practice and improve their writing. My program has a textbook that covers the five subjects on the TASC exam, but its writing section does not meet the needs of my students, who live in poor and working-class communities in New York City that are among the most racially segregated in the country. I have developed a series of essay prompts based on their lives that my students recognize and are encouraged to write about.

One of the advantages of this adult literacy program is that it has small classes. Twelve highly motivated students usually come to my morning classes. This small class size encourages wide-ranging discussions, making it possible for students to listen to and learn from each other. Critical thinking skills develop that allow students to apply their thoughts and life experiences to the essays I assign. Students who volunteer to read their essays in class receive a wealth of feedback and support from other students that often surprises me.

Small classes make it possible to assign regular essays primarily during class but also for homework. I hand back their essays with as many corrections as needed and detailed comments. In New York City's Black and Latinx working-class high schools, most teachers have five classes a day, 5 days a week. Only the most dedicated English teachers will assign and correct 750 essays over the course of 1 week. This system is bound to fail.

\section{Writing Assignments for Adult Literacy Students}

The 50-minute essay on the TASC exam is graded by hand. I ask my students to practice outlining their response to a prompt before they write. The template I give them calls for a main idea in the introduction, three to five paragraphs of supporting details, and an appropriate conclusion or a lesson learned from the subject matter of the essay. Since practice is essential, I assign an essay every week over the course of a 13 -week semester.

In the first week of the semester, I hand out an essay that is based on a quote by Terry McMillan: "Can't nothing make your life work if you ain't the architect" (Bell, 1996, p. 8). This open-ended prompt is meant to encourage students to open up and write about their lives. It is also valuable to me in assessing where each of my students is on the continuum of writing skills. 
In response to McMillan, Robert wrote: "I will rebuild and fulfill my dreams and hopes on a positive path with no looking back on the negative downfalls. I will focus on much greater things in life, not just for me but for my family." Amadou explained: "I have many friends but I'm the one to go back to school. My friends have decided to do two jobs and to make more money than me. I know that after my studies I will earn more money than those who have decided to not go back to school. This gives me more strength to reach my goals in this country."

A second essay is based on a quote by Spike Lee from By Any Means Necessary: The Trials and Tribulations of The Making of Malcolm X: "Presently in America a war is being fought. At stake is the way to control the way people think, act or be passive" (Bell, 1996, p.37). Below are excerpts from essays by three young AfricanAmerican and Latinx students on the subject of images of African- Americans in the media. From TV to the internet and to social media, my students know a great deal about this subject.

\section{RuQuiya wrote: "My viewpoint on the} stereotypical African-American is one of pain and disappointment. When it comes to the men, they are aggressive, scary, dangerous, etc. For AfricanAmerican women like myself, we are often seen as disrespectful, crazy, rude, etc. On TV, AfricanAmerican women get the worst treatment, being displayed as sex slaves and mistresses. This leads me to believe that the media is consistently assassinating the characteristics of AfricanAmericans. With all of that disrespect, I believe slavery never ended. It's just in a different form."

Katarina explained: "In America we are fighting a battle of discrimination, even though things have changed a little from the past. No matter how much money, education or hard work we have achieved, we are still fighting a war against racism. No matter how the mass media wants to make us look, we decide who we want to be."

Charles wrote: "My viewpoint on images of African-Americans is that they are always portrayed to be criminals, thieves, etc. Every time you hear some white people speak of AfricanAmericans, they always bring up how they are uneducated and are 'ghetto' or drug dealers. There's so much more to Black people."

An essay in the last part of the semester asks students whether 12 million undocumented workers from Mexico and other countries should have a pathway to become U.S. citizens (Gonzalez, 2011). I expect to receive a range of viewpoints among my Latin American and African-American students on this controversial question.

The students from Latin America supported such a pathway. A Peruvian woman wrote: "We left everything in our countries looking for a better quality of life and to help our families. We take jobs that American people are not interested in. It's hard for us to be in the illegal 'shadows,' when we can be separated from our children. This is the worst nightmare." A middle-aged African American woman wrote that immigrants should become citizens because they "have come to work." Two younger African American students said that undocumented workers should apply for citizenship through legal channels.

In the middle of the semester, students write an important essay on the subject of why they dropped out of their high schools. This is directly relevant to twin goals: understanding the period before they joined the TASC program and gaining a deep understanding of their life, family, and work experiences.

In one semester, 11 students replied to this 
prompt, with a rich description of obstacles they have faced, including uncaring high school teachers, family turmoil, poverty, unsafe schools, unplanned pregnancy, and getting stuck in deadend special education programs. Many of these essays appeared in the program's journal at the end of the semester.

RuQuiya wrote a powerful description of her journey from childhood to this TASC program in Harlem: "At one point in my life, I was a great student. My grandmother made sure I was in good Catholic schools and got tutoring. She made sure I was given a proper education. When I was 16 years old, I was on my way to Georgia to find my mom, only to find out that she was mentally unstable and didn't take education seriously. I missed out on my first semester of $9^{\text {th }}$ grade. When I finally made it to $11^{\text {th }}$ grade, I felt left out. Everyone in my classes went to $12^{\text {th }}$ grade, and I was still in the $11^{\text {th }}$. I had no confidence. I felt I had no hope of passing. . . One day a big situation happened between me and my mother. I left home, which means I left school. I went back to New York to stay with my grandmother. Now my goal is to get my G.E.D. and start nursing school. Never let someone stop you from what you deserve."

Vanessa wrote that she got pregnant in the $11^{\text {th }}$ grade. "I felt like my life was over so I stopped going to school. I stopped hanging out with my friends. I went to my doctor and found out I lost my baby. I never wanted to go back to my old school or see my old friends. I felt like I was going to get judged, and people would say I faked my pregnancy. Five months later I decided to come to the TASC program to get my G.E.D."

Carnetta explained: "I left high school because my parents did not have enough money to take care of their 10 children. I had to get a job at the age of 17 , and I started selling drugs. My mom told me that you have consequences that result from the choices that you make. I didn't listen to my mom. My punishment was going to jail. That was a wake-up call up for me. When I got out of jail, I decided to go back to school."

Carlos wrote: "The main reason I didn't graduate high school was because certain teachers didn't teach me, but only stressed me. It got to the point that I didn't even want to go to school. I would get little to no help when I needed it. They ruined it for me. I didn't have the self-motivation I needed to go to school every single day."

Juliette explained: "In junior high school and high school, I went to some of the best public schools in the Montreal area. The issue with my mom was that she always told me that when I turn 18 yrs. old I needed to move out. I started having problems with concentration in school. So I left school at the $11^{\text {th }}$ grade and started working at McDonald's, Burger King, supermarkets and every silly job. I am so happy I moved to NYC in 2002. I have a little girl who is turning five years old, and I want to read to her as she grows up."

Varenda came to live in the United States with her mother when she was 9 years old. She was placed in a third grade special education class instead of the fourth grade. "When I started high school, I still had to be in Special Education classes until the teacher decided that I no longer needed to be in there. But that never happened. Feeling like I'll never get out of the Special Ed class, I stopped participating in class. I got there late, ate, fell asleep and laughed with the other students. But I never did work."

Gina wrote that she was the product of a "broken school system." Her family moved from Puerto Rico to New York City in the late 1960s. "My mother dropped out of school in $3^{\text {rd }}$ grade because she didn't have any shoes to wear to school. In 
New York, I learned English by watching TV and listening to the radio. I missed out on someone reading to me at home as a child. I wished that I had someone showing me the way. I was passed from grade to grade without knowing how to read or write. When it came to $11^{\text {th }}$ grade, I dropped out of high school. So here I am at the age of 55, trying to get a high school diploma."

After working on 13 essays over the course of a semester, nearly all of my students' writing, including their grammar, spelling and organization, show a marked improvement. Some of the students who have relatively strong writing skills at the beginning of the semester move to a higher, more sophisticated level, including in the length of their essays. The students who begin with relatively weak writing skills make the most visible improvements. Wherever they are on the writing skills continuum, my students demonstrate that they are better able to write about their thoughts and feelings, especially about their families and jobs.

\section{Conclusion}

Though my intermediate Level 2 students are not ready to take the TASC, most of them graduate to Level 3 or 4, which have a greater focus on exam preparation. I do not automatically receive TASC test scores, possibly with student privacy concerns in mind. However, some students have shown their test scores to me and asked for suggestions on strategies they can use for future study and test-taking.

We also participate in an important celebration. At the end of a semester, the program hosts an evening celebration of student achievement at a church in Harlem. Many family members, friends, teachers, and staff members attend. Essays by many of my students are published in the TASC program booklet, which is distributed at this event. This is the first time that these students have been published and recognized by their peers. They are still on the journey, but they already are becoming "architects" of their lives.

The experiences of these students also point to the urgent need to transform New York City's segregated, working-class Black and Latino high schools. Many of the strategies that I have used to teach writing and empower students in this adult literacy program can be applied to teaching writing in these high schools to keep students from dropping out in the first place. An alliance of students, progressive teachers, parents, and community-based organizations can be a force to fight for high-quality schools in these communities. 


\section{References}

Bell, J. C. (1996). Victory of the spirit: Meditations on the Black experience. Warner Books.
Gonzalez, J. (2011). Harvest of empire: A history of Latinos in the U.S. Penguin Books. 